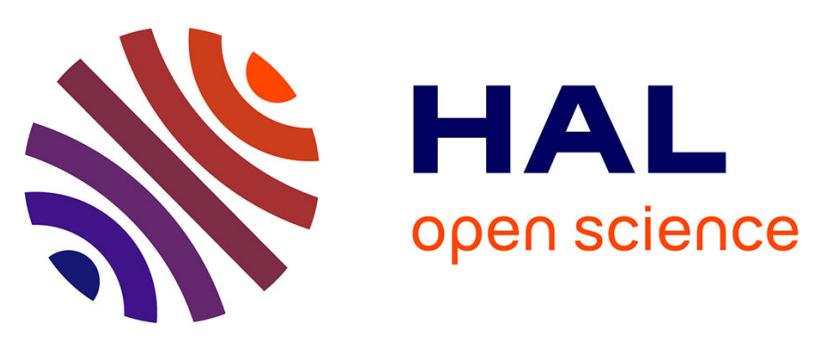

\title{
HIGHLY EXCITED VIBRATIONAL STATES OF CYCLIC MOLECULES INVESTIGATED BY I.C.L.A SPECTROSCOPY WITH PHOTOACOUSTIC DETECTION
}

\author{
L. Lespade, S. Rodin, D. Cavagnat, S. Abbate
}

\section{To cite this version:}

L. Lespade, S. Rodin, D. Cavagnat, S. Abbate. HIGHLY EXCITED VIBRATIONAL STATES OF CYCLIC MOLECULES INVESTIGATED BY I.C.L.A SPECTROSCOPY WITH PHOTOACOUSTIC DETECTION. Journal de Physique IV Proceedings, 1991, 01 (C7), pp.C7-517-C7-520. 10.1051/jp4:19917136 . jpa-00250809

HAL Id: jpa-00250809 https://hal.science/jpa-00250809

Submitted on 1 Jan 1991

HAL is a multi-disciplinary open access archive for the deposit and dissemination of scientific research documents, whether they are published or not. The documents may come from teaching and research institutions in France or abroad, or from public or private research centers.
L'archive ouverte pluridisciplinaire HAL, est destinée au dépôt et à la diffusion de documents scientifiques de niveau recherche, publiés ou non, émanant des établissements d'enseignement et de recherche français ou étrangers, des laboratoires publics ou privés. 


\title{
HIGHLY EXCITED VIBRATIONAL STATES OF CYCLIC MOLECULES INVESTIGATED BY I.C.L.A SPECTROSCOPY WITH PHOTOACOUSTIC DETECTION
}

\author{
L. LESPADE, S. RODIN, D. CAVAGNAT and S. ABBATE* \\ Laboratoire de Spectroscopie Moléculaire et Cristalline, Université de Bordeaux I, \\ 351 cours de la Libération, F-33405 Talence, France \\ *Istituto di Chimica Fisica, Università di Palermo, Via Archirafi 26, Palermo, Italy
}

\begin{abstract}
The spectra of the fourth and fifth $\mathrm{CH}$ stretching overtones of cyclohexene and cyclopentene molecules and of some of their selectively deuterated derivatives have been measured by dye laser intracavity spectroscopy with photoacoustic detection. The intramolecular relaxation of the vibrational energy occurs principally through Fermi resonances with $\mathrm{CH}_{2}$ bending combinations in cyclohexene and through a coupling between the stretching and the ring puckering motions in cyclopentene.
\end{abstract}

\section{I-INTRODUCTION}

Vibrational overtone spectroscopy in gases is a usefull tool to investigate the intramolecular redistribution of the vibrational energy at wavenumbers well suited for laser photochemistry.In very small molecules like water,highly excited vibrational states are very localised allowing photoinduced selective chemical reactions to be performed(1). When a large amplitude motion exists in the molecule, the coupling between the excited states and the motion may complicate the vibrational energy redistribution(2).The purpose of our work is to investigate how these motions affect the highly excited vibrational states in two cyclic molecules which undergo a large amplitude motion with barrier of different height.

The first molecule, cyclohexene, possesses a high barrier of inversion between the halfchair conformation and its mirror image $(5 \mathrm{kcal} / \mathrm{mole})(3)$. The cyclohexene average life time before inversion being of the order of $10^{-9} \mathrm{~s}$ at $25^{\circ} \mathrm{C}$, the spectra are expected to show no coupling effect with the large amplitude motion. To make more precise attributions, we have studied the perhydrogenated (h10) molecule and one of its selectively deuterated substitute: the 3,3,6,6-d4 derivative (d4).

The second molecule,cyclopentene, is known to possess a relatively low ring puckering barrier $(0.66 \mathrm{kcal} / \mathrm{mole})(4)$. During the motion, the two conformations interconvert rapidely $\left(5.10^{12} \mathrm{~s}^{-1}\right.$ at $\left.25^{\circ} \mathrm{C}\right)$. The highly excited vibrational states $(\Delta v=6$ and 7$)$ of the perhydrogenated molecule had been previously measured (5). But the large width of the absorptions did not allow any evidence of a coupling between the overtones and the large amplitude motion.Thus, we have chosen to study also two selectiveiy deuterated molecules: the $1,2,3,4,4,5,5-d_{7}$ cyclopentene (here called $3 \mathrm{~h} 1$ ) and the 4,4,5,5-d4 derivative (here called $3 \mathrm{~h} 2$ ).

\section{II-EXPERIMENTAL SET-UP.}

Highly excited vibrational states have very low transition probabilities. Roughly, the $\mathrm{CH}$ stretching overtone spectra loose one order of magnitude in intensity when going from the transition $0 \rightarrow v$ to the next one $0 \rightarrow v+1$. Thus the measure of the $\Delta v=5$ and 6 
transitions which occur between 13000 and $17000 \mathrm{~cm}^{-1}$ impose a very sensitive technics.Intracavity dye laser spectroscopy incorporating photoacoustic detection is well suited to detect overtone transitions of medium size molecules with large absorptions.

Photoacoustic effect was first discovered by A.G Bell in $1880(6)$. It has been used for overtone spectroscopy in gas for the first time by Reddy et al(7) in 1977.

A shematic diagram of our spectrometer version is shown in fig 1. The pump laser is a 4 Watt Ar ion laser (Coherent Innova 70). It is chopped and pumps a Coherent 599 dye laser. The photoacoustic cell, placed inside the cavity, is an home-made stainless steel non resonant cell with fused siliced windows at Brewster angle to reduced light reflections. The windows are not sealed but pressed to the cell by tapered joints. Thus, they can easily be removed for cleaning. At laser wavelenghts which correspond to overtones transitions, the photoacoustic effect induces pressure waves which are detected by a small hearing aid microphone mounted at the midpoint of the cell. Power fluctuations in the dye laser are measured through a photodiode which detects scattered light from a Brewster angle window. The scanning of the dye laser and the collection of the data (from microphone or diode) are controlled by a microcomputer.Before being digitalized, the data are filtered by two lock-in amplifiers (EG\&G models 5207 and 5101) to remove all ambiant noise possible. The dye laser wavelenghts are controlled by a PHO spectrometer to within $\pm 2 \mathrm{~cm}^{-1}$.

Fig 1: A shematic diagram of the intracavity dye laser spectrometer with photoacoustic detection.

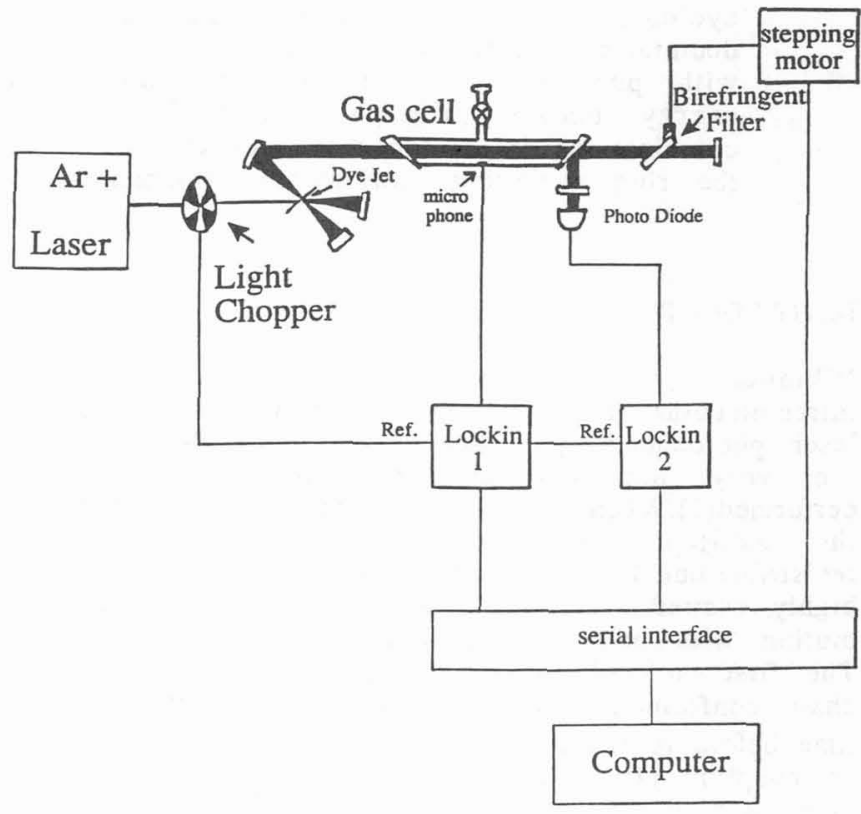

III-CYCLOHEXENE SPECTRA.

The $\Delta \mathrm{v}=5$ and 6 spectra of cyclohexene $\mathrm{h}_{10}$ and $\mathrm{d}_{4}$ are displayed in fig 2 . For the deuterated compound one would expect two absorptions of equal intensities corresponding to the pseudo-axial and pseudo-equatorial $\mathrm{CH}$ bonds. A deconvolution of the $\Delta \mathrm{v}=5$ spectrum reveals at least five bands of unequal intensities indicating strong intramolecular energy relaxation. A modelization of all the overtones spectra $(\Delta \mathrm{v}=1,3,4,5$ and 6$)$ with an Halmitonian incorporating couplings between the $\mathrm{CH}$ stretchings and Fermi resonances with the $\mathrm{CH}_{2}$ bendings combinations (8) indicates that both experimental frequencies and intensities can be understood by a rapid redistribution of the energy on combinations states involving the $\mathrm{CH}$ stretchings and $\mathrm{CH}_{2}$ bendings.This model can also explain the intensity difference of the two main bands of the $\Delta v=6$ polyad without involving an intrinsic difference in intensity between the $\mathrm{CH}$ pseudo-axial and $\mathrm{CH}$ pseudo-equatorial stretching transitions as previously suggested(5). 


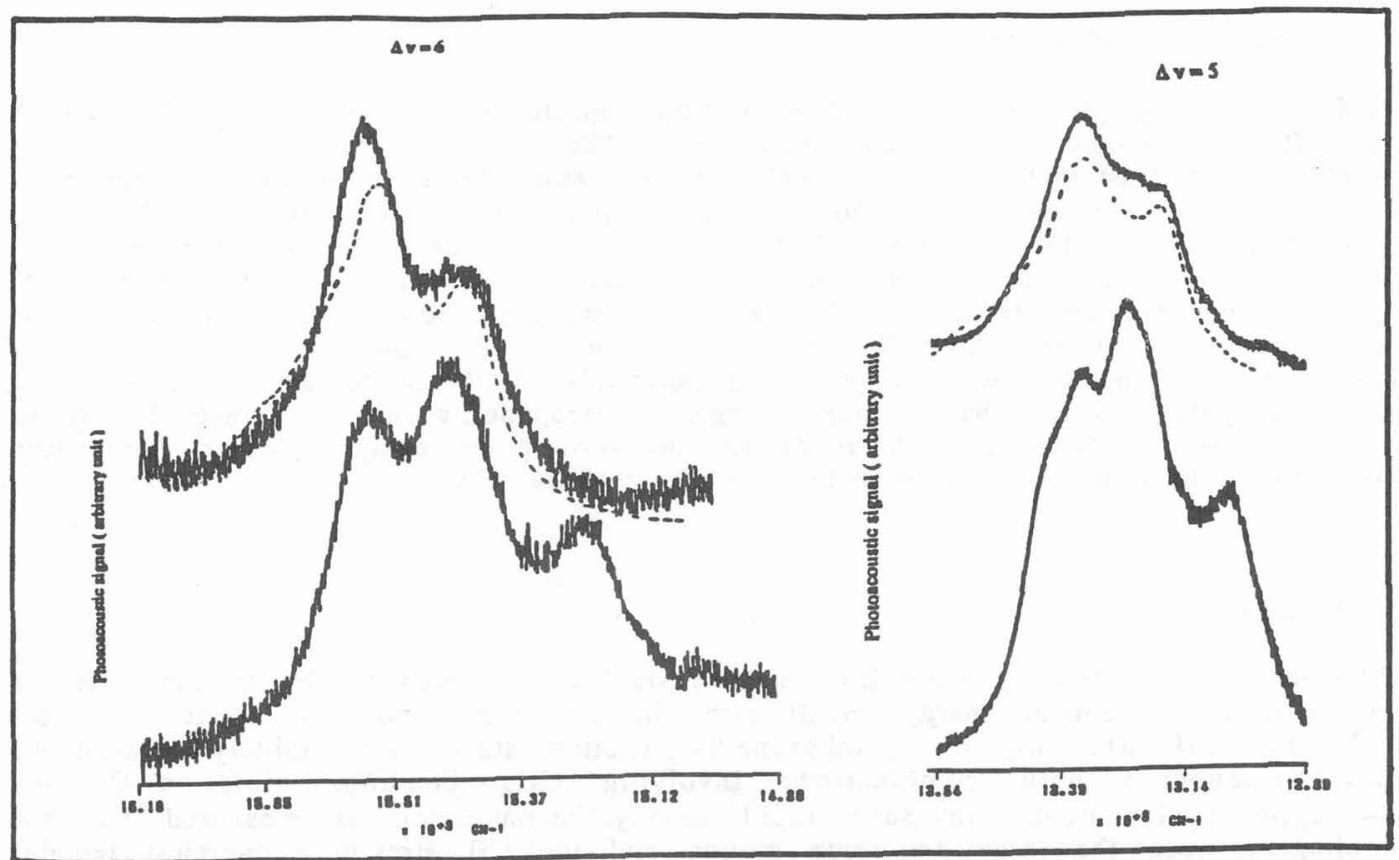

Fig 2: Gas phase overtone spectra of cyclohexene (bottom) and 3,3,6,6-d4 cyclohexene (top) in the methylenic regions of $\Delta y=5$ and 6 .The spectra were detected in a $12 \mathrm{~cm}$ lenght cell at a sample pressure corresponding to the room temperature vapour pressure.The broken lines correspond to the calculated spectra of cyclohexene d4 with an Hamiltonian analogous to the one described in ref 8.

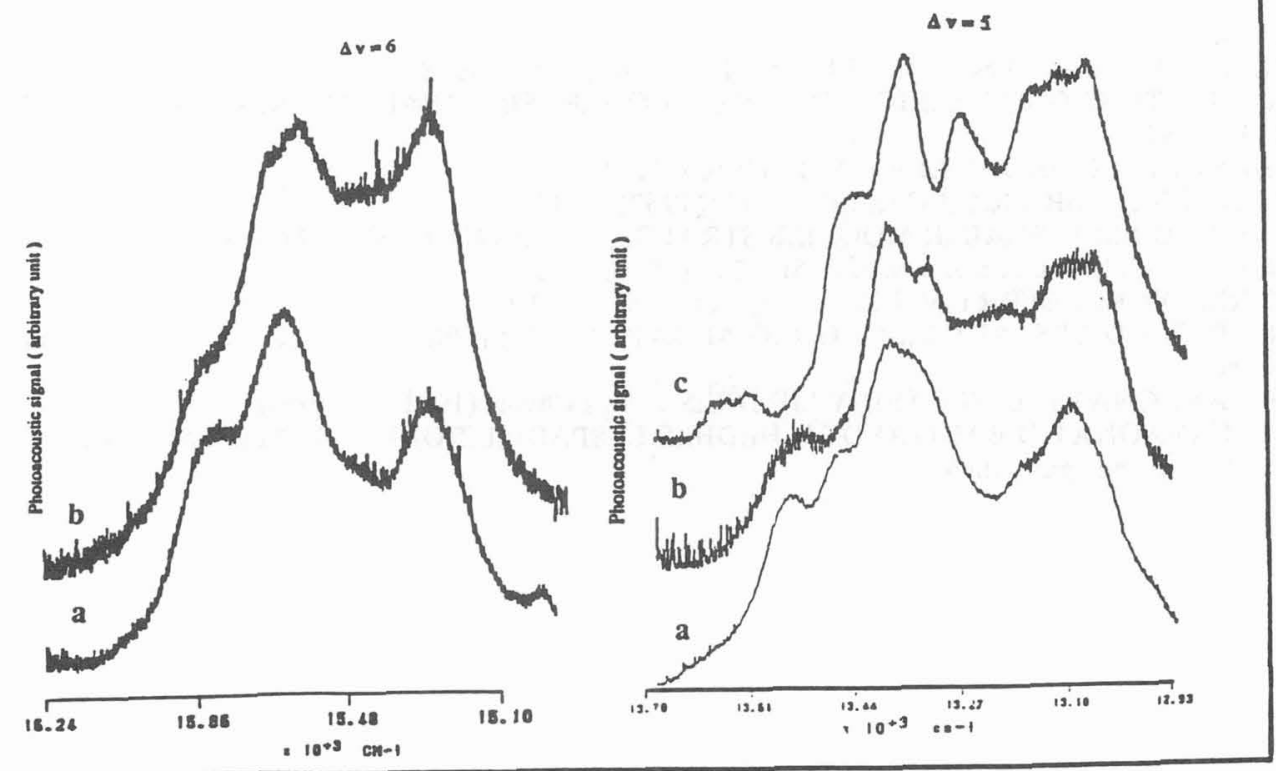

Fig 3: Gas phase overtone spectra of cyclopentene (a), 1,2,3,4,4,5,5-d7 cyclopentene (b) and 4,4,5,5-d4 cyclopentene (c) in the methylenic regions of $\Delta v=5$ and 6 . The spectra were recorded in a $12 \mathrm{~cm}$ lenght cell at a sample pressure corresponding to the room temperature vapour pressure for (a) and (c) and to 30 torr for (b) in the $\Delta v=5$ region. 


\section{IV-CYCLOPENTENE SPECTRA.}

On fig 3 are displayed the $\Delta v=5$ and 6 overtones spectra of the methylenic vibrations of the different isotopic cyclopentene derivatives. The $3 \mathrm{~h} 1$ monohydrogenated compound spectra show at least three bands for $\Delta v=6$ and much more for $\Delta v=5$ polyads. Furthermore, the spectra of the two $3 \mathrm{~h} 1$ and $3 \mathrm{~h} 2$ compounds are similar indicating that, in cyclopentene, there are no strong Fermi resonances with bending combinations as for the cyclohexene molecules. Thus, all the absorptions correspond to transitions with different quantum numbers in the ring puckering motions. However the spectra are not exactely identical for the three compounds : this may come from the differences in the reduced masses and in the ring puckering potentials of the three molecules. The ring puckering potentials at the various energies corresponding to $\Delta y=5$ and 6 may be differently perturbed by the difference in the zero point energies which have been shown to be important for the asymmetry of the potential (9).

\section{V-CONCLUSION.}

Although the two sorts of molecules we have studied are relatively similar, they undergo very different vibrational energy redistribution in the fourth and fifth overtones of the methylenic $\mathbf{C H}$ stretchings.In cyclohexene, the excited states are rapidely relaxed by Fermi resonances with combinations involving $\mathrm{CH}_{2}$ bendings vibrations.On the contrary, in cyclopentene, no such rapid energy reconversion is measured but the coupling between the large amplitude motion and the $\mathrm{CH}$ stretching overones remains very strong. Work is in progress to determine the ring puckering potential form at these high energies.It becomes more and more dissymetric but there is no evidence of a strong localization of the stretching energy in one of the potential well (10).

REFERENCES.

/1/SINHA,A,HSIAO,M,CRIM,F,J.Chem.Phys 94 (1991) 4928

/2/ABBATE,S,LONGHI,G,RICARD,L,BERTUCCI,C,ROSINI,C,SALVADORI,P, MOSCOWITZ,A,J.A.C.S 111 (1989) 836

/3/ANET,F,A,L,HAO,M,Z,J.A.C.S 87 (1965) 3147

14/LAANE,J,LORD,R,C,J.Chem.Phys 47 (1967) 4941

I5/WONG,J,MACPHAIL,R,MOORE,B,STRAUSS,H,J.Phys.Chem 86 (1982) 1478

/6/BELL, A,G,Proc.Am.Assoc.Adv.Sci 29 (1880) 115

17/REDDY,K,V,BERRY,M,J,Chem.Phys.Letters 52 (1977) 111

18/ RICARD-LESPADE,L,LONGHI,G,ABBATE,S, Chem.Phys 142 (1990) 245 and unpublished work.

19/CAVAGNAT,D,BANISAED-VAHEDIE,S,J.Phys.Chem (1991) in press /10/CAVAGNAT,D,BANISAED-VAHEDIE,S,LESPADE,L,RODIN,S,J.Chem.Soc. Faraday Trans. 2 (1992) to be published. 